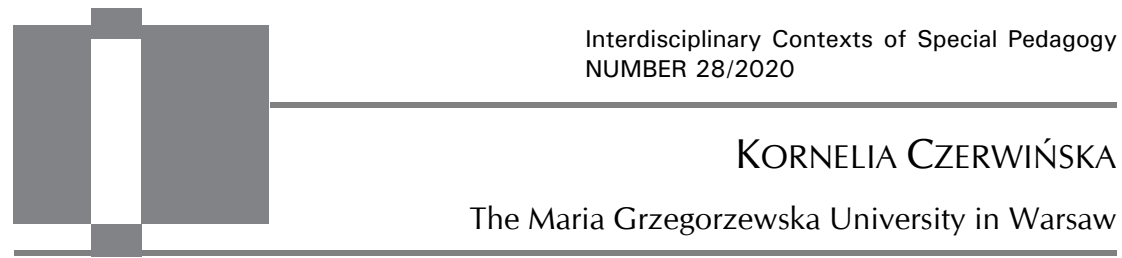

\title{
Gradual loss of vision and performing the role of father
}

[...] I relaxed because I already knew what to say and where we were. Since the appearance of Tess in our lives, these minutes were the nicest and gave me an idea of what really can mean raising a child. I passed on knowledge. I explained something to my daughter. With my every word her world grew bigger, each name led her out of the fog into human specificity. [...] God, what a fantastic feeling. I heartily recommend.

"C'mon Papa: Dispatches from a Dad in the Dark" R. Knighton

ABSTRACT: Kornelia Czerwińska, Gradual loss of vision and performing the role of father. Interdisciplinary Contexts of Special Pedagogy, no. 28, Poznań 2020. Pp. 37-60. Adam Mickiewicz University Press. ISSN 2300-391X. e-ISSN 2658-283X. DOI: https://doi.org/10.14746/ikps.2020.28.03

Performing social roles, including family-related ones, by people with visual impairment is associated with experiencing various types of difficulties It is basically a consequence of the socially established negative image of these people who are perceived as not fully competent and requiring assistance. Previous few studies devoted to the motherhood of blind and partially sighted women indicate relatively frequent reactions of their social environment expressing the belief that a visually impaired woman is not able to perform her role as a wife and mother in a proper way. The psychosocial situation of fathers with visual impairment is rarely analysed in research activities, and knowledge of the relationship between gradual loss of vision and experience of fatherhood is relatively poor. The aim of the article is to present the results of a qualitative study focused on learning the subjective experience of performing the role of a parent by a man with progressive vision loss.

In the biographical study of an individual case, the narrative interview technique was used, and the analysis of the collected material was referred to such 
spheres of experiencing fatherhood as: the concept of role, sources of satisfaction and positive experience related to the role, perceived relationships between the way of performing the role and progressive impairment.

KEY WORDS: visual impairment, vision loss, progressive vision loss, fatherhood, individual case study

\section{Introduction}

The dynamic changes currently occurring in the social macrosystem, mainly related to the processes of globalisation, industrialisation and constantly increasing autonomy of the individual, are directly reflected in the functioning of a family. The gradual broadening of the social definition of the family, combined with the high heterogeneity of modern forms of family life, implies changes in public space. The cultural transformation of this sphere of existence is particularly evident in significant changes in the area of parental roles, both in terms of social expectations towards their undertaking, as well as types and methods of performing tasks assigned to parents according to their gender. Traditional family models focused on the permanence of the system, characterised by a stable and hierarchical system of intergenerational relationships, recognised parenthood as a natural element of adult life and closely associated it with the marital role. ${ }^{1}$ The gradual departure from the pattern of extended and patriarchal families contributed to the consideration of parenthood not as an obligation, but as the right of each individual and a consciously chosen developmental task that is a potential source of self-creation experience. Parental roles are evaluated by adults of both genders as the most satisfying compared to marital and professional roles. ${ }^{2}$

${ }^{1}$ L. Bakiera, Zaangażowane rodzicielstwo a autokreacyjny aspekt rozwoju dorostych, Difin, Warszawa 2013, pp. 125-130.

${ }^{2}$ K.M. Perrone, L.K. Webb, R.H. Blalock, “The effects of role congruence and role conflict on work, marital, and life satisfaction", Journal of Career Development, no. $31(4), 2005$, pp. $225-238$. 
Cultural, social and demographic changes observed in European countries (e.g. lower stability of marriages, debut as a father at an older age, greater professional activity and financial independence of women, raising children in reconstructed families) affect family positions and roles, leading to a transformation of motherhood and fatherhood. In traditional concepts, father's tasks were reduced to securing the family life in material terms and ensuring its safety and coherence. Performing the function of the main family supporter obligated the man to increased professional activity leading to economic success and high social position. Fatherhood was associated with the authority, knowledge and power entitling to make decisive choices regarding individual family members. The man as a mentor introducing his descendant into the world of social norms at the same time kept a distance from everyday experience of his child. At present, the authoritarian and dominant attitude is opposed by the tendency to involve the father more in the daily care and upbringing of the child, which favours building a close relationship based on mutual understanding and respect. The new dimension of fatherhood implies the need for greater availability and active presence of a man at home, as well as constant care for maintaining positive contacts with the child. The promotion of equality and the increase in the active participation of women in public life, including in particular their activity in the labour market, led to the perception of the father as an equal partner of the mother in the care and support of child development in every area. ${ }^{3}$

The function of a responsible guardian and educator performed by fathers, as well as active participation in fulfilling the obligations related to household management, increasingly often become a topic of public debates aimed at developing such systemic solutions that would effectively support men in shaping new parenting patterns. It should be noted that despite attempts of European countries to introduce various types of tools in the sphere of family poli-

3 A. Błasiak, ,(Nowy) wymiar rodzicielstwa - wybrane aspekty", [in:] Rodzicielstwo w wybranych zagadnieniach pedagogicznych, (eds.) D. Opozda, M. Leśniak, Wydawnictwo Episteme, Lublin, 2017, pp. 36-37. 
cy strengthening the model of active fatherhood, performing this role raises some tensions and doubts. The lack of adequate socialisation patterns generates the need to develop new strategies of operation, and the broadening of the role to include numerous aspects previously reserved only for motherhood raises anxiety and exposes men to experiencing overload. In addition, present expectations concerning fatherhood are often contradictory, and beliefs about the need for practical and emotional participation in the growth and raising of a child starting from conception to independence are accompanied by the continuing requirement to provide financial security for the family, mainly by a man. The situation is further complicated by the progressing differentiation of parenthood forms related to the breakup of relationships and the establishment of subsequent relationships, in which the provisions that constitute a social role of the father include many different connections and different parenting and educational relationships. ${ }^{4}$

Parental roles are not static and their changes are not conditioned only by the specificity of a given period of history. Adoption of a developmental perspective tends to define the family as circumstances of the life course of individuals in an interdependent relationship, so parental roles, including fatherhood, will change within the life cycle of a given person, as well as in successive phases of the family functioning as a system. ${ }^{5}$ Studies confirm the variability in perception of parental role in ontogeny. People in different developmental periods (early and late adolescence, early, middle and late adulthood) differ in the structure, content and evaluation of the father's image. ${ }^{6}$

${ }^{4}$ M. Racław, Postawy Polaków wobec ojcostwa - wybrane aspekty w świetle badań społecznych, Report "Rola ojca i postawy Polaków wobec ojcostwa w świetle badań społecznych" 2013, Chancellery of the Senate, Warsaw, pp. 15-17.

${ }^{5}$ M. Tyszkowa, Rozwój jednostki w cyklu życia: teoria i metodologia badań, Poznań Society of Friends of Learning of Adam Mickiewicz University, Poznań, 2010, pp. 86-89.

${ }^{6}$ A. Kurcbart, Psychologiczny obraz ojca w biegu życia, Difin, Warsaw, 2011, pp. 57-86. 
The complexity and dynamic transformation of parental roles require a multidisciplinary, in-depth analysis enabling the design of effective strategies to support women and men in undertaking and performing these roles. The issues related to fulfilling paternal functions seem to be definitely less recognised, because childcare had been identified for many years only with the person of the mother. Therefore, understanding and description of the specific nature of the father's role, considering its various variants in individual family structures, is becoming an important research task. It is emphasised that survey research normally applied in social studies do not provide data describing the emotional and mental presence of a particular parent in family life, and do not record all significant relationships between the activities of mother and father. ${ }^{7}$ National studies concerning fatherhood are still relatively scarce and do not cover all thematically important areas. ${ }^{8}$ The issues that concern performing this role in minority groups (including single fathers, men with disabilities, and adoptive fathers) are particularly little recognised and researched.

\section{Visual impairment and parental roles}

Statistical data concerning the number of parents with disabilities obtained in demographic analyses conducted in selected countries, including Poland, indicate a steady upward trend in this group. ${ }^{9}$ Although families in which at least one of the parents expe-

${ }^{7}$ M. Racław, Postawy Polaków wobec ojcostwa - wybrane aspekty w świetle badań społecznych, Report "Rola ojca i postawy Polaków wobec ojcostwa w świetle badań społecznych" 2013, Chancellery of the Senate, Warsaw, pp. 15-16. Ch. Lewis, M.E. Lamb, "Fathers' influences on children's development: The evidence from two-parent families", European Journal of Psychology of Education, no. 18(2), 2003, pp. 211-228.

8 A. Marzec-Tarasińska, “Oddziaływania wychowawcze ojców a poglądy młodzieży na temat roli ojca w rodzinie“, Wychowanie w Rodzinie, no. XIII(1), 2016, p. 259.

${ }_{9}$ P.E. Kaniok, “Rodzice z niepełnosprawnością - przegląd wybranych wyników badań zagranicznych", Niepetnosprawność i Rehabilitacja, no. 1, 2014, pp. 66-67. 
riences disability constitute a fairly large percentage of the general population, the issue of their situation is still rarely studied in theoretical and scientific analyses, especially in the context of relationships between the role of the father and the occurrence of a certain type of dysfunction. ${ }^{10} \mathrm{~A}$ review of international andragogy research on families of origin performed by Beata Borowska-Beszta, Urszula Bartnikowska and Jerzy Stochmiałek showed that explorations in this area regarding disability in the children subsystem are undertaken more often than in case of parents. There is no reliable, evidence-based scientific knowledge regarding significant phenomena constituting the everyday lives of these families, including analyses focused on factors and circumstances other than the dysfunction that affect the quality of life of families and their individual members. The authors emphasise the dominance of research focused above all on the barriers, difficulties and burdens in families with a disabled parent, which consequently build a negative image of those families, ignoring coping strategies, the use of the accessible resources and the occurrence of positive consequences of living in the family system. ${ }^{11}$ Neglected areas are also noticed in the national system of practical help and specialist support in the field of rehabilitation psychology, in which the issues of functioning of marriages of people with disabilities and their families are ignored. ${ }^{12}$

Previous explorations concerning the fatherhood of men with disabilities were mainly conducted in the interpretive paradigm and provided cognitively valuable material illustrating the high diversity of individual experience and the multitude of meanings assigned to them. Studies conducted among men with various types of dysfunctions revealed numerous difficult situations, taking the form of

${ }_{10}$ M. Kilkey, H. Clarke, "Disabled men and fathering: opportunities and constraints", Community, Work E Family, no. 13(2), 2010, pp. 127-146.

11 B. Borowska-Beszta, U. Bartnikowska, J. Stochmiałek, “Niepełnosprawność w rodzinie jako «wartość dodana». Międzynarodowe andragogiczne badania nad rodzinami generacyjnymi“, Niepetnosprawność i Rehabilitacja, no. 1, 2016, pp. 79-81.

12 S. Kowalik, Psychologia rehabilitacji, Wydawnictwa Akademickie i Profesjonalne, Warsaw, 2007, pp. 225-235. 
deprivation, overload, threat and impediments encountered in daily functioning and performing tasks related to fatherhood. Factors that negatively affected performing a parental role included, among others, problems with finding a job, low income, incurring additional expenses related to the disability and negative social attitude, leading in some cases to actions resulting in discrimination and exclusion.

At the same time, having children and fulfilling caring and educational functions was a source of positive experience and constituted an important element of the identity of men with disabilities. ${ }^{13}$

Interesting data was also collected in narrative interviews conducted in a group of over 30 men who related their experience to the general category of experience typical for fathers regardless of their health and physical function. In the statements, there were no signs of emphasising disability, and the difficulties listed by the respondents were not predominantly linked to the negative consequences of their dysfunctions. ${ }^{14}$ The most often perceived categories of limitations related to childcare, play, work and direct contact with the child, and the awareness of these problems was a result of a comparison with other fathers and their possibilities, generating a sense of unrealised desires. An important element of the structure of experiencing limitations in performing the role of a father was the compensatory role of the environment, including the takeover of some parental responsibilities by an able-bodied partner. Because of low income or inability to perform gainful employment, the surveyed fathers had considerable difficulties in satisfying the material needs of the family, and therefore they felt emotional discomfort resulting from the failure to meet the social expectations still attrib-

${ }^{13}$ M. Kilkey, H. Clarke, "Disabled men and fathering: opportunities and constraints", Community, Work \& Family, no. 13(2), 2010, pp. 127-146.

14 U. Bartnikowska, K. Ćwirynkało, “Wyzwania współczesnego ojcostwa w narracjach niepełnosprawnych mężczyzn", [in:] Teoria i praktyka oddziatywań profilaktyczno-wspierających rozwój osób z niepetnosprawnościa, (eds.) G. Gunia, D. Baraniewicz, Wydawnictwo Naukowe Uniwersytetu Pedagogicznego, Cracow, 2014, pp. 108-113. 
uting to the man the role of the main family supporter. This experience was particularly painful for men who lost their fitness in adulthood and had difficulty adapting to the new situation and adopting the status of a person with a disability. Interestingly, the lower professional activity of the fathers did not correlate with greater involvement in daily household chores. ${ }^{15}$

Disability is a complex and heterogeneous category, which in the context of parenting-related considerations is of great importance and implies the necessity to take into account a number of interrelated internal and external factors affecting the relationship between damage to the body and performing social roles. ${ }^{16}$

In order to identify specific problems and strategies to overcome them, it is necessary to focus, among others, on the period of acquisition of disability in the life cycle, the nature of the dysfunction (stabilised vs. progressive) and the type and degree of disability. Polish and foreign studies concerning the experience of fatherhood by men with a dysfunction were generally conducted in groups with high heterogeneity, so the conclusions were usually quite general, and information on issues specific to individual types of disability was fragmentary. However, the gathered empirical data allows for the identification of certain issues characteristic for the experience of fathers with visual impairment. The narratives of the surveyed men included the following issues:

- reproduction-related dilemmas related to the risk of inheriting serious eye diseases, 17

- problems to ensure the safety of the child when moving in an open and (or) little-known space, and during spontaneous

15 U. Bartnikowska, K. Ćwirynkało, “Niepełnosprawność mężczyzny a możliwości i ograniczenia w realizowaniu roli ojca", Problemy Edukacji, Rehabilitacji i Socjalizacji Osób Niepetnosprawnych, no. 20(1), 2015, pp. 66-79.

16 B. Górnicka, “Wybrane aspekty funkcjonowania osób z niepełnosprawnością w rolach rodzicielskich", Annales Universitatis Mariae Curie-Skłodowska LublinPolonia, Vol. XXVIII, no. 1, 2015, p. 100.

17 A. Nowakowska, "Rodzicielstwo osób z różnymi rodzajami niepełnosprawności“ , Niepetnosprawność. Dyskursy Pedagogiki Specjalnej, no. 31, 2018, pp. 123-124. 
play 18 and the resulting need to use the assistance of sighted people, including the mother, ${ }^{19}$

- inability to drive a car independently, which makes moving with the child difficult (the necessity to use public transport, dependence on able-bodied family members in terms of transport).

More detailed analyses can be found in visual impairment pedagogy publications concerning the psychosocial functioning of blind and partially sighted adults.

Among the few studies focused on parenthood in the case of visual impairment, the vast majority are analyses concerning motherhood, including above all the challenges related to the childcare of the infant. ${ }^{20}$ The rich material about parental roles of this group of people comes from a study conducted by Marzenna Zaorska in a group of 35 people with visual impairment (16 men and 19 women), among whom as much as $89 \%$ acquired dysfunctions in their adulthood. It is worth emphasising that much attention was paid to learning the ways in which respondents perceive family roles attributed to a given gender. In the perception of male roles, apart from the tasks determined by the traditional father/husband model (e.g. taking responsibility for the material and social situation of the family, participating in making decisions regarding individual family members, supporting the development and education of chil-

18 U. Bartnikowska, K. Ćwirynkało, “Niepełnosprawność mężczyzny a możliwości i ograniczenia w realizowaniu roli ojca", Problemy Edukacji, Rehabilitacji i Socjalizacji Osób Niepetnosprawnych, no. 20(1), 2015, pp. 76-77.

${ }^{19}$ U. Bartnikowska U., K. Ćwirynkało, “Wsparcie społeczne z perspektywy ojców z niepełnosprawnością", Niepetnosprawność. Dyskursy Pedagogiki Specjalnej, no. 13, 2014, pp. 127-131.

${ }^{20}$ Cf. K. Czerwińska, I. Kucharczyk, Tyflopsychologia. Realizacja zadań rozwojowych w biegu życia przez osoby z niepetnosprawnościa wzroku, Wydawnictwo Naukowe PWN, Warsaw, 2019, pp. 147-171. M. Wałachowska, “Specyfika macierzyństwa kobiet z niepełnosprawnością wzroku", [in:] Tradycja $i$ wspótczesność pedagogiki specjalnej w tworzeniu społeczeństwa dla wszystkich, (eds.) J. Głodkowska, K. Sipowicz, I. Patejuk-Mazurek, Wydawnictwo Akademii Pedagogiki Specjalnej, Warsaw, 2018, pp. 160-167. 
dren), there were functions and activities typical of modern model of engaged fathering (including active participation in family life, childcare and playing with offspring, creating a safe climate and care for the well-being of family members). The respondents, when describing their difficulties in performing family roles, indicated tasks in which eyesight plays an important role, i.e. dealing with administrative matters, playing with children, helping in learning and maintaining contact with school, using means of transport, activities that require access to information. In the opinion of the respondents, the source of these problems are not only the functional consequences of diseases and damage to the visual system that negatively affect the quality of everyday activities, but also social barriers, including the stereotypical perception of blind and partially sighted people as not competent and the distance expressed by ablebodied people resulting from anxiety and lack of knowledge about this type of disability. Among the determinants of difficulties appearing in families, the lack of access to professionals specialising in working with adults with visual impairment was also mentioned. ${ }^{21}$

The impact of negative social attitudes experienced by blind and partially sighted people on their functioning in the family was also noticed in other studies. While able-bodied people participating in the diagnostic survey conducted by Hanna Żuraw associated blind people with mainly positive features, they perceived them as financially dependent on their families or social assistance institutions, being unemployed or achieving unsatisfactory earnings.

Over half of the respondents did not connect the lives of the blind with having a family and competent performing of social roles related to marriage and parenthood. Perception of the blind as lonely, weak, dependent and unhappy was associated with reluctance to have frequent contacts with this category of people. ${ }^{22}$ Similar results

${ }^{21}$ M. Zaorska, "Role małżeńskie w percepcji osób dorosłych z niepełnosprawnością wzrokową", [in:] Nauka. Edukacja. Praca, (eds.) U. Jeruszka, J. Łaszczyk, B. Marcinkowska, F. Szlosek Wydawnictwo Akademii Pedagogiki Specjalnej, Warsaw, 2018, pp. 285-294.

${ }^{22}$ H. Żuraw, “Koncepcje osób niewidomych w poglądach osób z wykształceniem średnim", Szkoła Specjalna, no. 3, 2008, pp. 165-174. 
were obtained in surveys conducted by Marta Kasperska and Iwona Bodyk-Cupak. $64 \%$ of respondents believed that visual impairment hinders the involvement in emotional relationships and family life. According to respondents (28\%), adults with visual impairments are lonely, passive (34\%), experience frustration (38\%) and face a lack of acceptance from their environment (44\%). ${ }^{23}$ Myths about the impossibility of raising children in accordance with the norms adopted in a given cultural circle seem to still be present in the social image of the blind and partially sighted. ${ }^{24}$

Negative beliefs and social reactions towards parenthood of people with visual impairment significantly increase the risk of marginalisation and favour the acquisition of non-constructive coping strategies, such as avoiding contacts or masking disparaging traits. In the group of visually impaired people and those who gradually lose their vision, the strategy of hiding visual problems treated as an embarrassing attribute exposing to discrimination is observed particularly often. ${ }^{25}$ The stigma masking strategy, although it helps to avoid negative reactions in some situations, is ineffective in the longer term and involves high psychological costs $^{26}$ such as constant fear of being unmasked. ${ }^{27}$ Then, performing

${ }^{23}$ M. Kasperska, I. Bodys-Cupak, “Funkcjonowanie psychospołeczne niewidomych i słabowidzących w opinii osób z dysfunkcją wzroku oraz osób pełnosprawnych", Niepetnosprawność i Rehabilitacja, no. 4, 2012, pp. 8-10.

24 B. Szabała, "Stereotypowy wizerunek osób niewidomych", [in:] Dystans społeczny wobec osób z niepetnosprawnościa jako problem pedagogiki specjalnej, (eds.) M. Parchomiuk, B. Szabała, Wydawnictwo Uniwersytetu Marii Curie-Skłodowskiej, Lublin, 2012, pp. 89-100.

25 J. Gładyszewska-Cylulko, “Autostygmatyzacja osób z niepełnosprawnością wzrokową", Interdyscyplinarne Konteksty Pedagogiki Specjalnej, no. 22, 2018, pp. 192-193. K. Czerwińska, "Stopniowa utrata wzroku a wypełnianie ról społecznych w dorosłości“, [in:] Tyflopedagogika wobec różnorodności wspótczesnych wyzwań edukacyjnorehabilitacyjnych, (eds.) K. Czerwińska, K. Miler-Zdanowska, Wydawnictwo Akademii Pedagogiki Specjalnej, Warsaw, 2017, pp. 202-209.

${ }^{26}$ L. Smart, D.M. Wegner, "Ukryte koszty ukrytego piętna", [in:] Społeczna psychologia piętna, (eds). T.F. Heatherton, R.E. Kleck, M.R. Hebl, J.G. Hull, Wydawnictwo Naukowe PWN, Warsaw, 2008, pp. 205-245. 
parental tasks is associated with increased emotional tension that reduces psychophysical well-being.

Many of the above-mentioned studies of parenthood, including fatherhood, of people with visual impairment, were implemented in a qualitative strategy based on phenomenological and interpretive understanding of reality. The dominance of qualitative research is associated with the position which is increasingly common position in special education and recommends this method of analysing the family and intimate life of people with disabilities because of the possibility of a more in-depth, multidimensional learning of subjective experience, sensations and impressions related to personal spheres. ${ }^{28}$

\section{Fatherhood in the experience of a person gradually losing their vision}

The undertaken own research was conducted in the qualitative paradigm, and it is focused on the subjective experience of performing the role of a father by a person who gradually loses their vision. As a research method, a biographical case study was selected, which in the opinion of Tadeusz Pilch and Teresa Bauman "(..) enables the exploration of the internal structure of the studied phenomenon, e.g. it allows for the penetration into the significance of experience lived by a blind person (...) or also for the perception of external conditions of their existence" ${ }^{29}$ Description and analysis of the individual history of a studied person along with various factors

${ }^{27}$ K. Pietrowiak, Świat po omacku. Etnograficzne studium (nie)widzenia i (nie)sprawności, Wydawnictwo Naukowe Uniwersytetu Mikołaja Kopernika, Torun, 2019, p. 261.

28 This issue is further explained in: R. Kijak, Dorośli z głębsza niepetnosprawnościa intelektualna jako partnerzy, małżonkowie i rodzice, Oficyna Wydawnicza "Impuls", Cracow, 2017, pp. 116-129.

${ }^{29}$ T. Pilch, T. Bauman, Zasady badań pedagogicznych. Strategie ilościowe i jakościowe, Wydawnictwo Akademickie „Żak”, Warsaw, 2001, p. 299. 
conditioning its course become possible thanks to the biographical method, which "(...) allows for the exploration of the subjective experience of the studied people and, therefore, perception of the problem which is important for the researcher from their own perspective, or in a way through their eyes (...) makes it possible to learn more about what and how happens around the studied people (or how and what they are witnessing every day or in exceptional circumstances), is reflected in their consciousness, opinions, beliefs, attitudes, aspirations, as well as in the values, norms and principles they recognize" ${ }^{30}$

In the study, the narrative interview technique, which formulates material including the events of the respondent current life into a specific structure, within which statements about self-understanding of their own situation, experienced emotions, motives for actions and undertaken activities are incorporated, was applied. ${ }^{31}$ As observed by Magdalena Żurko, based on the data obtained in this way "it is possible to describe the way of experiencing and living a parental role. Interpretation of narrative material allows for the reconstruction the narrator's intentional attitudes to their role, revealed in the described episodes (events)" ${ }^{32}$ The author did not make an attempt to obtain the full autobiography and its structure, but she focused on the selected segment of the respondent's life history regarding his parental role. The following specific research problems have been formulated:

- What is the concept of the role of the father adopted by the respondent?

${ }^{30} \mathrm{M}$. Łobocki, Metody $i$ techniki badań pedagogicznych, Oficyna Wydawnicza "Impuls", Cracow, 2003, p. 309.

31 E. Kos, "Wywiad narracyjny jako metoda badań empirycznych", [in:] Badania jakościowe w pedagogice. Wywiad narracyjny i obiektywna hermeneutyka, (eds.) D. Urbaniak-Zająć, E. Kos, Wydawnictwo Naukowe PWN, Warsaw, 2013, pp. 93-97.

${ }^{32}$ M. Żurko, "Doświadczanie ojcostwa w świetle narracji mężczyzn w okresie średniej dorosłości“, [in:] Psychologia matych i wielkich narracji, (eds.) M. Straś-Romanowska, B. Bartosz, M. Żurko, Wydawnictwo Psychologii i Kultury, Warsaw, 2010, p. 159. 
- What is the source of satisfaction in undertaking and performing the role of the father for the respondent?

- What are the relationships between the consequences of gradual loss of vision and the way of performing the role of the father perceived by the respondent?

At the time of the interview, the respondent had been married for 28 years. For the first time he became a father at the age of 23, and for the second time at the age of 31. Because of binocular congenital cataract, nystagmus and a secondary form of glaucoma, the respondent suffered from numerous diseases affecting his everyday functioning. As a result of the reduced visual acuity, visual field loss and the increased demand for light, he experienced difficulties in the process of learning in the public education system and sharing free time activities with able-bodied peers. Constantly worsening visual problems during the adolescence period aroused in the respondent strong anxiety and numerous fears related to potential difficulties in establishing a lasting relationship leading to parenthood. This fear was further strengthened by the opinions of parents who in the presence of the respondent expressed their doubts about the possibility of raising a family by their son who was gradually losing his vision. In the statements referring to the personal concept of fatherhood, the respondent emphasised several times that the mere fact of having a family can be considered in his case a kind of success in life.

And what else is fatherhood to me? The joy that I could be a father, given my visual impairment, because not all disabled people can have this experience. To this day, I remember the concern of my parents, who were repeating «(...) what will happen to our Andrzej, will he find a wife, will he have children (...)?». Fatherhood is for me happiness that I could raise (as I think well) my children - together with my wife, to become good and valuable people and I hope that my children bring up their children, my grandchildren, in the same way or better [voice crack caused by emotions].

When defining tasks of a man in performing a parental role, the respondent mentioned a number of tasks and responsibilities (in- 
cluding care, concern, assistance, development support, material support, education focused on the transmission of values and norms) and forms of interaction with the father (e.g. performing careproviding and upbringing activities, spending time together, talking, playing, learning, modelling the right behaviour, participating in problem solving and accompanying in difficult situations). According to the narrator, all actions taken by the father, with the significant involvement of the mother, should be aimed at equipping the child with competencies that will allow them to independently achieve their life goals and dreams in the future. It is worth emphasising that the respondent, despite a detailed description of numerous practical aspects of fatherhood, perceives this role as a kind of unique relationship with a metaphysical dimension.

Fatherhood is for me something special that cannot be defined. It is like my nature, my second "me", but it is also a certain expectation of fulfilling unrealised dreams, which of course will not be realised, because each person is different and unique (...) in my case, fatherhood is a kind of relationship with a daughter or son, I do not know how to call it, such an unconditional relationship, despite different beliefs or different outlook upon life. I used to wonder whether a father or mother can recognise their child they have not seen for many years, or whether there is something incomprehensible that connects a parent with their child. I think the aswer is yes. For me, fatherhood is a pride of being a father and at the same time anxiety about the future of the child. And one more slogan, which to me is true. A child for me will always be a child despite their adulthood.

The most common topic of the episodes described in the interview were educational interventions, especially during school age and adolescence, dictated by the desire to protect the daughter and son from the consequences of bad choices, as well as resulting from a sense of parental responsibility understood as the need to explain the principles of morally proper behaviour. According to the respondent, such explanation should be combined with teaching and disciplining.

Extensive self-narrative material showed many threads of experiencing fatherhood, including referring to positive emotional experi- 
ence, which transformed along with the progressing development of children and gradual accumulation of experience in the efficient fulfilment of parental tasks. Information about the pregnancy of the narrator's wife released his great joy and became for him a source of other strong, hard to identify positive emotions. The infancy and post-infancy period was associated primarily with a sense of responsibility, but also with the feeling of concern and tenderness during direct contact with children. Pre-school and early school age was indicated by the narrator as the period, which was most satisfying for him as a father mainly because of the extraordinary intimacy experienced in the relationship with his offspring.

At the beginning, the joy of becoming a father and such an unimaginable, wonderful feeling that I still remember today. I am not able to describe this feeling, but it was amazing and I have never experienced anything like this again (...) The most satisfying period in performing my role of the father role was the period when the children attended kindergarten and the first years of elementary school. Of course, every stage of the development of my children was important to me, but the aforementioned period is the time when children are so"sweet", keep their eyes fixed on the father, with unconditional love. This is the period when children want to be with their parents, sit on their knees, hug and parents are the most important for them. I have the best memories of this period and I cannot wait for my grandchildren to reach this age.

In turn, the period of adolescence of children, especially of the daughter, is described from the angle of numerous conflicts and educational problems. The narrator indicated complex causes of difficult situations occurring in the family at that time, noticing, apart from the specific characteristics of this stage of development, the incorrectness of his actions, including a tendency to slightly excessive control and rigour in enforcing requirements. The respondent perceived positive impact of his wife on the functioning of the whole family system at the time, as well as on the systematic broadening of his competencies as a father. The wife not only eased the emerging conflicts on an ongoing basis, but also vividly explained to the respondent the needs of an adolescent child, including the need for independence and self-determination, as well as 
forms of expressing opinions typical of adolescents. Thanks to the support of his wife, the narrator managed, despite many misunderstandings, to maintain a positive relationship with his children, which was even deepened when the daughter and son became adults.

It is important for the father to be supported by the mother of the child, who will help him become aware of the moment when he makes a mistake that could destroy the child-father relationship. My children, going through this period, became wise and valuable people, without distorting their moral fibre and without leaving the determined path. And from a time perspective, I consider this to be my greatest achievement as a father, my parental success. Despite some of my mistakes at this stage in my children's lives, I think I successfully passed my parenthood exam. And this emotion, when I hear from my children, I am sure that honestly spoken words: "Dad, I love you. You were and you are a great father»".

The respondent associated his parental role and fulfilling his tasks of the father for many years with the acquisition, development and (or) improvement of numerous internal resources such as patience, prudence, sensitivity, responsibility, resourcefulness, empathy and creativity.

Interestingly, narratives regarding the family sphere contained relatively frequent references to gradual loss of vision experienced by the respondent, although in his opinion this dysfunction did not significantly interfere with fulfilling parental responsibilities. The problem of visual impairment treated as a stigma that requires to be hidden was revealed already during the period of dating with the future wife of the respondent, when he was making inefficient attempts to mask his perceptual limitations (e.g. he did not wear glasses for a meeting, which prevented him from recognising the face of his partner). From the perspective of numerous years of marriage, the respondent recalled with amusement his actions and surprise at the fact that his wife from the beginning of their relationship was fully aware of his vision problems. The topic of his low vision reappeared in the description of the spouses' conversations 
about parental plans and related concerns about passing on health burden to the offspring.

The problem of my low vision and its consequences started to be important for me and my wife when we decided to become parents. We went together to my ophthalmologist and simply asked about the probability of our children to inherit my vision-related diseases. The ophthalmologist could not say anything about it, therefore we left the physician with the same knowledge which we had before, which means none. We were afraid of a glaucoma, congenital cataract, nystagmus, poor vision in our possible child and we didn't know anything about what could happen in this respect. In a sense, we took a risk, and in a sense it was by chance and after some time we had a healthy daughter with good vision. We felt a big relief. Then a healthy son with good vision was born.

The already adult son had some ophthalmology conditions requiring constant medical check-ups, however, however the respondent treated this subject quite marginally in the interview. When analysing the successive stages of the upbringing of the daughter and son, the narrator pointed to numerous difficulties such as constant fatigue, sleep deficit, exhaustion, economic uncertainty, and educational dilemmas. However, he devoted a lot of attention to those situations in which his low vision had a negative impact on the effectiveness of undertaken childcare and upbringing activities. He described negative feelings most commonly experienced in connection with:

- inability to ensure the safety of his children in an open space, especially during walks and when using moving equipment in parks and playgrounds,

- problems in precise and quick childcare activities,

- limitations concerning help provided during doing homework.

The respondent also recognised the lack of full freedom and spontaneity in activities undertaken together with children as a certain inconvenience, which resulted from the need for constant attention and concern for their safety, which under the conditions of impaired vision of the guardian was more difficult to achieve. It should be 
noted that only some of the described problematic situations were directly related to the functional consequences of the experienced visual system diseases. Certain events were rather the result of the use of non-constructive coping strategies by the respondent, based on incomplete acceptance of his dysfunction. For example, during individual consultations in the course of a parents-teacher meeting, the narrator did not inform a teacher of his son that he is a visually impaired person and cannot see the marks shown in the table on the computer screen, as a result of which he did not get any information about school achievements of his child and teachers considered him to be a rather uncommunicative parent.

Care of a newborn and infant was problematic. As a visually impaired person, I had significant difficulties and fears in situations when my wife was at work, and I had to deal with personal hygiene of an infant, to bath, change a nappy, clean, etc. On the one hand, I was afraid to do these activities because of low vision, and on the other hand I was so unskillful in these tasks. When I was carrying the infant in my arms while lulling them to sleep or in some other situations, low vision did not help either. This was because I had to be careful not to drop the child and not to fall over with them or fall on something standing on the floor [...] Once I lost my 5-year-old son on a walk, because he was playing in the sandpit and suddenly he was not there, because he went to a swing, and I could not see him, and I began to look for him intensively until one lady who was nearby brought him to me, seeing what was happening.

In the development of children, the infancy, pre-school and early school age are those stages, at which the narrator very often experienced difficulties in performing the role of the father resulting from progressive visual impairment. Taking a retrospective perspective, the respondent considered these years as a particularly difficult stage of his parenthood and emphasised the effectiveness of the support he received at that time from his able-bodied wife as a partner and a person co-responsible for the process of raising children. It should be remembered, however, that the early childhood of the daughter and son was identified by the narrator as the period of feeling the greatest satisfaction from his parenthood. 


\section{Summary}

The image of fatherhood presented in the analysed narrative showed the extraordinary multidimensionality of this life experience. This role was considered by the respondent in terms of a particular challenge implying a number of responsibilities, at the same time perceived as a source of strong, positive experience resulting from the unique nature of the relationship between the father and his children. The wide range of activities and tasks of the narrator is part of the content of the modern model of fatherhood, emphasising the importance of the active participation of men in the process of raising children by adopting the role of a guardian, educator, everyday playmate consciously and systematically building an intimate, affective relationship with the child. Issues related to the perception of the role of a man as the main family supporter, which in the collected material seem to be treated marginally, require further research. This issue seems to be important because of the observed and persistent difficulties of people with disabilities in finding an economically satisfactory job.

The evaluation of the relationship between gradual loss of vision and performing the role of the father in the analysed material is quite ambivalent. The narrator declares that his disability did not significantly impede performing this role, but at the same time he describes in detail numerous events from the early childhood of his daughter and son, in which visual impairment as well as its functional and psychological consequences negatively affected the fulfilment of his parental responsibilities. Therefore, the experience of numerous problematic situations did not lead the man to form a belief that his visual impairment had a limiting impact on the achievement of parental goals, which was probably associated with the supportive activities taken by his wife. The narrator repeatedly mentioned his partner in the context of his parenting, emphasising the diversity of her tasks and functions. His wife took over the duties that absolutely required good vision, while in other tasks she 
helped him develop the most effective strategies to compensate for impaired vision. In addition, she facilitated the understanding of the specific nature of children's functioning in successive stages of development, thereby correcting improper educational practices performed by the respondent. The narrator perceived a common dimension of fatherhood and motherhood, and emphasised shared experience related to raising children. The presence of wife, strongly marked in the narratives of the respondent seems to have a direct connection with his dysfunction, because in the study conducted by Magdalena Żurko, most able-bodied men did not mention at all their wives as partners and mothers in their narratives. ${ }^{33}$ Interesting data could be provided by scientific analyses aimed at understanding correlations between marital relationships and the concept of the role of the father, including men with visual impairment.

It should be noted that in the narratives there was no information about the negative reactions of the social environment towards the visually impaired man as a father, on the contrary the respondent experienced signs of approval, understanding and help in crisis situations. It can be assumed that to some extent the lack of this type of negative experience was the result of his strategy of hiding his visual problems.

The gender of the respondent could also play an important role, because, as shown by the results of numerous studies, ${ }^{34}$ mainly women experience multiple discrimination in the area of performing social roles because of overlapping stereotypes regarding both gender and disability.

${ }^{33}$ M. Żurko, „Doświadczanie ojcostwa w świetle narracji mężczyzn w okresie średniej dorosłości", [in:] Psychologia małych i wielkich narracji, ed. M. Straś-Romanowska, B. Bartosz, M. Żurko, Wydawnictwo Psychologii i Kultury, Warsaw, 2010, pp. 165-166.

${ }^{34}$ E. Ciaputa, A. Król, M. Warat, “Genderowy wymiar niepełnosprawności. Sytuacja kobiet z niepełnosprawnościami wzroku, ruchu i słuchu", [in:] Polscy niepetnosprawni. Od kompleksowej diagnozy do nowego modelu polityki społecznej, ed. B. Gąciarz, S. Rudnicki, Wydawnictwa AGH, Cracow, 2014, pp. 280-281. 


\section{References}

Bakiera L., Zaangażowane rodzicielstwo a autokreacyjny aspekt rozwoju dorostych, Difin, Warsaw, 2013.

Bartnikowska U., Ćwirynkało K., “Niepełnosprawność mężczyzny a możliwości i ograniczenia w realizowaniu roli ojca", Problemy Edukacji, Rehabilitacji i Socjalizacji Osób Niepetnosprawnych, no. 20(1), 2015, pp. 63-79.

Bartnikowska U., Ćwirynkało K., “Wsparcie społeczne z perspektywy ojców z niepełnosprawnością", Niepetnosprawność. Dyskursy Pedagogiki Specjalnej, no. 13, 2014, pp. 124-138.

Bartnikowska U., Ćwirynkało K., “Wyzwania współczesnego ojcostwa w narracjach niepełnosprawnych mężczyzn", [in:] Teoria i praktyka oddziaływań profilaktycznowspierających rozwój osób z niepetnosprawnością, (eds.) G. Gunia, D. Baraniewicz, Wydawnictwo Naukowe Uniwersytetu Pedagogicznego, Cracow 2014, pp. 105-114.

Błasiak A., "(Nowy) wymiar rodzicielstwa - wybrane aspekty", [in:] Rodzicielstwo w wybranych zagadnieniach pedagogicznych, (eds.) D. Opozda, M. Leśniak, Wydawnictwo Episteme, Lublin, 2017, pp. 29-43.

Borowska-Beszta B., Bartnikowska U., Stochmiałek, J., “Niepełnosprawność w rodzinie jako «wartość dodana». Międzynarodowe andragogiczne badania nad rodzinami generacyjnymi“, Niepetnosprawność $i$ Rehabilitacja, no. 1, 2016, pp. 72-88.

Ciaputa E., Król A., Warat M., “Genderowy wymiar niepełnosprawności. Sytuacja kobiet z niepełnosprawnościami wzroku, ruchu i słuchu“, [in:] Polscy niepełnosprawni. Od kompleksowej diagnozy do nowego modelu polityki społecznej, (eds.) B. Gąciarz, S. Rudnicki, Wydawnictwa AGH, Cracow, 2014, pp. 275-334.

Czerwińska K., "Stopniowa utrata wzroku a wypełnianie ról społecznych w dorosłości", [in:] Tyflopedagogika wobec różnorodności wspótczesnych wyzwań edukacyjno-rehabilitacyjnych, (eds.) K. Czerwińska, K. Miler-Zdanowska, Wydawnictwo Akademii Pedagogiki Specjalnej, Warsaw, 2017, pp. 189-211.

Czerwińska K., Kucharczyk I., Tyflopsychologia. Realizacja zadań rozwojowych w biegu życia przez osoby z niepetnosprawnościa wzroku, Wydawnictwo Naukowe PWN, Warsaw, 2019.

Gładyszewska-Cylulko J., “Autostygmatyzacja osób z niepełnosprawnością wzrokową", Interdyscyplinarne Konteksty Pedagogiki Specjalnej, no. 22, 2018, pp. 185-200, doi: 10.14746/ikps.2018.22.11.

Górnicka B., “Wybrane aspekty funkcjonowania osób z niepełnosprawnością w rolach rodzicielskich, Annales Universitatis Mariae Curie-Skłodowska LublinPolonia, Vol. XXVIII, no. 1, 2015, pp. 99-128, doi: 10.17951/j.2015.28.1.99.

Kaniok, P.E., “Rodzice z niepełnosprawnością - przegląd wybranych wyników badań zagranicznych", Niepetnosprawność i Rehabilitacja, no. 1, 2014, pp. 66-73. 
Kasperska M., Bodys-Cupak I., “Funkcjonowanie psychospołeczne niewidomych i słabowidzących w opinii osób z dysfunkcją wzroku oraz osób pełnosprawnych", “Niepetnosprawność i Rehabilitacja, no. 4, 2012, pp. 4-15.

Kilkey M., Clarke H., "Disabled men and fathering: opportunities and constraints", Community, Work \& Family, no. 13(2), 2010, pp. 127-146.

Kos E., „Wywiad narracyjny jako metoda badań empirycznych”, [in:] Badania jakościowe w pedagogice. Wywiad narracyjny i obiektywna hermeneutyka, (eds.) D. Urbaniak-Zająć, E. Kos, Wydawnictwo Naukowe PWN, Warsaw, 2013, pp. 91-116.

Kowalik S., Psychologia rehabilitacji, Wydawnictwa Akademickie i Profesjonalne, Warsaw, 2007.

Kurcbart, A., Psychologiczny obraz ojca w biegu życia, Difin, Warsaw, 2011.

Lamb M.E., The Role of the Father in Child Development, John Wiley\&Sons, New York, 2010.

Lamb M.E., “Fathers' influences on children's development: The evidence from twoparent families", European Journal of Psychology of Education, no. 18(2), 2003, pp. 211-228.

Łobocki M., Metody i techniki badań pedagogicznych, Oficyna Wydawnicza "Impuls", Cracow, 2003.

Marzec-Tarasińska A., “Oddziaływania wychowawcze ojców a poglądy młodzieży na temat roli ojca w rodzinie“" Wychowanie w Rodzinie, no. XIII(1), 2016, pp. 257-276, doi: 10.23734/wwr20161.257.276.

Nowakowska A., "Rodzicielstwo osób z różnymi rodzajami niepełnosprawności“, Niepetnosprawność. Dyskursy Pedagogiki Specjalnej, no. 31, 2018, pp. 116-131.

Perrone K.M., Webb L.K., Blalock R.H., “The effects of role congruence and role conflict on work, marital, and life satisfaction", Journal of Career Development, no. 31(4), 2005, pp. 225-238.

Pietrowiak K., Świat po omacku. Etnograficzne studium (nie)widzenia i (nie)sprawności, Wydawnictwo Naukowe Uniwersytetu Mikołaja Kopernika, Torun, 2019.

Pilch T., Bauman T., Zasady badań pedagogicznych. Strategie ilościowe i jakościowe, Wydawnictwo Akademickie “Żak”, Warsaw, 2001.

Racław M., Postawy Polaków wobec ojcostwa - wybrane aspekty w świetle badań społecznych, Raport "Rola ojca i postawy Polaków wobec ojcostwa w świetle badań społecznych" 2013, Chancellery of the Senate, Warsaw.

Smart L., Wegner, D.M., “Ukryte koszty ukrytego piętna“, [in:] Społeczna psychologia piętna, (eds.) T.F. Heatherton, R.E. Kleck, M.R. Hebl, J.G. Hull, Wydawnictwo Naukowe PWN, Warsaw, 2008, pp. 205-245.

Szabała B., "Stereotypowy wizerunek osób niewidomych", [in:] Dystans społeczny wobec osób z niepetnosprawnością jako problem pedagogiki specjalnej, (eds.) M. Parchomiuk, B. Szabała, Wydawnictwo Uniwersytetu Marii Curie-Skłodowskiej, Lublin, 2012, pp. 89-100.

Tyszkowa M., Rozwój jednostki w cyklu życia: teoria i metodologia badań, Poznań Society of Friends of Learning of Adam Mickiewicz University, Poznań 2010. 
Wałachowska M., „Specyfika macierzyństwa kobiet z niepełnosprawnością wzroku", [in:] Tradycja i wspótczesność pedagogiki specjalnej w tworzeniu społeczeństwa dla wszystkich, (eds.) J. Głodkowska, K. Sipowicz, I. Patejuk-Mazurek, Wydawnictwo Akademii Pedagogiki Specjalnej, Warsaw, 2018, pp. 155-172.

Zaorska M., "Role małżeńskie w percepcji osób dorosłych z niepełnosprawnością wzrokową", [in:] Nauka. Edukacja. Praca, (eds.) U. Jeruszka, J. Łaszczyk, B. Marcinkowska, F. Szlosek Wydawnictwo Akademii Pedagogiki Specjalnej, Warsaw, 2018, pp. 285-294.

Żuraw H., "Koncepcje osób niewidomych w poglądach osób z wykształceniem średnim", Szkoła Specjalna, no. 3, 2008, pp. 163-174.

Żurko M., “Doświadczanie ojcostwa w świetle narracji mężczyzn w okresie średniej dorosłości", [in:] Psychologia matych i wielkich narracji, (eds). M. Straś-Romanowska, B. Bartosz, M. Żurko, Wydawnictwo Psychologii i Kultury, Warsaw, 2010, pp. 157-168. 